\title{
COMMENT
}

\section{BID DEPOSITORY OPERATION: AN INVITATION TO BOYCOTT?}

In the recent case of Christiansen v. Mechanical Contractors Bid Depository ${ }^{1}$ defendant was a bid depository through which its members, a majority of the mechanical contractors in Utah, could submit subbids on building projects to general contractors. ${ }^{2}$ Upon request from a general contractor, the depository collected sealed subbids from its members and delivered them to the general contractor who was required to agree to use only the bids thus received in the preparation of his prime bid. ${ }^{3}$ The agreement was rigidly enforced, and violation could result in being denied further use of the depository; the names of general contractors who violated the agreement were sent to depository members. Plaintiff, a mechanical contractor who was not a member of the depository, brought suit against the depository ${ }^{4}$ alleging that the required agreement, inter alia, violated sections 1 and 2 of the Sherman Act.5 The court found that plaintiff "was substantially excluded from the opportunity of competing in the business bid through the Depository" ${ }^{6}$ and held that three depository rules, "representing as they do an agreement of the Depository with its members and

\section{F. Supp. 186 (D. Utah 1964).}

2 A general contractor usually enters into a single comprehensive contract in which he assumes responsibility for an entire construction project. $\mathrm{He}$ then subcontracts with mechanical contractors for specialized portions of the work. Therefore, in preparing a prime bid, a general contractor tusually solicits subbids on the specialized work in order to estimate his costs accurately. Obtaining the most favorable subbids will, of course, enable the general contractor to submit the lowest prime bid.

3 Depository rule $V$ provided that: "It is to be explicitly understood that the depository will forward bids to general contractors making request therefor [sic] with the understanding that the general contractor will use only bids thus received from the depository in preparing his bid." $230 \mathrm{~F}$. Supp. at 188.

It seems natural to assume that, in the event a general contractor were awarded the prime contract, he would be required to accept the subbid used in preparing the prime bid although this conclusion is not stated in the regulations.

4 This was a private suit filed under the Clayton Act $\$ 4,38$ Stat. 731 (1914), 15 U.S.C. \&15 (1964).

5 5 1 . Every contract, combination in the form of trust or otherwise, or conspiracy, in restraint of trade or commerce among the several States . . . is declared to be illegal ....

\$2. Every person who shall monopolize, or attempt to monopolize, or combine or conspire with any other person or persons, to monopolize any part of the trade or commerce among the several States . . . shall be deemed guilty of a misdemeanor ....

26 Stat. 209 (1890), as amended, 15 U.S.C. $\$ \$ 1-2$ (1964).

$6230 \mathrm{~F}$. Supp. at 194. 
the general contractors requesting Depository bids . . . constitute a conspiratorial contract and combination in restraint of interstate commerce." 7

While unilateral refusal to deal is recognized as a general right under the Sherman Act, ${ }^{8}$ a group boycott, or concerted refusal to deal, is illegal per se under section $1 .^{8}$ Group boycotts, typically involving a purpose to remove third parties from competition ${ }^{10}$ or to force their compliance with a pattern of conduct desired by the group ${ }^{11}$ are viewed as being so dangerous to competition that "inquiry as to the precise harm they have caused or the business excuse for their use" is irrelevant. ${ }^{12}$ Closely analogous to boycotts are agreements in which one of the participating parties agrees to deal exclusively with the other as a condition of doing business. ${ }^{13}$ Such agreements, generally involving legitimate business purposes, ${ }^{14}$ are illegal only if their practical effect is to foreclose nonparticipating parties from "a substantial share of the line of commerce affected." 16

TId. at 189. The court also held that the rules constituted an attempt to monopolize in violation of $\S 2$ but articulated no basis for so holding. Courts generally seem to reason that when an unreasonable restraint is found under $\$ 1$, a $\$ 2$ violation can be presumed, and defendants have the burden of clearing themselves of the predatory intent necessary for violation. See United States v. New Orleans Ins. Exch., 148 F. Supp. 915, 920 (E.D. La.), aff'd per curiam, 355 U.S. 22 (1957).

8 United States v. Colgate \& Co., 250 U.S. 300 (1919); see Times-Picayune Publishing Co. v. United States, 345 U..S. 594, 625 (1953). The right, however, is not absolute. An individual refusal to deal, if accompanied by other restrictive practices or agreements, see United States v. Parke, Davis \& Co., 362 U.S. 29 (1960); FTC v. Beech-Nut Packing Co., 257 U.S. 441 (1922), or conceived of with a monopolistic purpose, see Lorain Journal Co. v. United States, 342 U.S. 143 (1951), is illegal under the act.

9 Radiant Burners, Inc. v. Peoples Gas Light \& Coke Co., 364 U.S. 656 (1961) (per curiam) ; Klor's, Inc. v. Broadway-Hale Stores, 359 U.S. 207 (1959); Fashion Originators' Guild of America, Inc. v. FTC, 312 U.S. 457, 467-68 (1941) ; Handler, Recent Developments in Antitrust Law: 1958-59, 59 CoLUM. L. Rev. 843, 862-66 (1959).

10 See Radiant Burners, Inc. v. Peoples Gas Light \& Coke Co., supra note 9; Klor's, Inc. v. Broadway-Hale Stores, supra note 9; Barber, Refusals To Deal Under the Federal Antitrust Lazes, 103 U. PA. L. Rev. 847, 875-76 (1955).

11 See Fashion Originators' Guild of America, Inc. v. FTC, 312 U.S. 457 (1941);

Eastern States Retail Lumber Dealers' Ass'n v. United States, 234 U.S. 600 (1914).

12 Northern Pacific Ry. v. United States, 356 U.S. 1, 5 (1958); see Kirkpatrick, Commercial Boycotts as Per Se Violations of the Sherman Act, 10 GEO. WASH. L. REv. 387, 392 (1942).

13 See generally Report of Atr'y Gen. Nat'i Comar. Antitrust 137-49 (1955). 14 See id. at 145; Schwartz, Free Enterprise and Economic Organization 482 (2d ed. 1959).

15 Standard Oil Co. v. United States, 337 U.S. 293, 314 (1949) ; see Tampa Elec. Co. v. Nashville Coal Co., 365 U.S. 320, 325-29 (1961). Illegality is generally tested under $\S 3$ of the Clayton Act, which provides:

It shall be unlawful for any person engaged in commerce . . . to . . . make a sale or contract for sale of goods ... on the condition, agreement, or understanding that the ... purchaser thereof shall not use or deal in the goods ... of a competitor or competitors of the . . . seller, where the effect of such . . . sale, or contract for sale . . . may be to substantially lessen competition or tend to create a monopoly in any line of commerce.

38 Stat. 731 (1914), 15 U.S.C. \$14 (1964). However, not all exclusive dealing arrangements fall within the specific terms of the act, and illegality may be tested under the broader terms of the Sherman Act. See, e.g., Times-Picayune Publishing Co. v. United States, 345 U.S. 594, 609-10 (1953); United States v. Investors Diversified Servs., 102 F. Supp. 645 (D. Minn. 1951). 
Thus in exclusive dealing arrangements, the per se doctrine of group boycotts is not applicable and it is necessary to determine the precise effect of the agreement.

The procedure by which general contractors secure cost estimates and negotiate subcontracts on portions of a building project to be performed by subcontractors has been the subject of considerable controversy. ${ }^{\mathbf{1 6}}$ Basically, the general contractor is free to solicit secret competitive subbids or to bargain for subcontractors' services on the open market, and there is no evidence of any compelling economic reason to limit his freedom to use either method or both. ${ }^{17}$ Subcontractors, however, urge that such freedom often leads to "unfair" negotiating tactics on the part of general contractors ${ }^{18}$ and thus have expressed a preference for limiting the

16 Since 1932 federal legislation has been proposed to exercise a degree of control over this procedure by requiring general contractors to name the subcontractors they intend to engage when submitting prime bids on government projects. Schueller, Bid Depositories, 58 MICH. L. REv. 497, 503-06 (1960).

Although their methods differ, a few states have enacted legislation to control the procedure. One approach is similar to that proposed for federal legislation. ARK. Stat. ANN. \$14-613 (Supp. 1963); CaL. Gov'T CoDE \$ 4104 . Another approach is the so-called separate contract system in which subcontractors submit their subbids directiy to the awarding authorities and are awarded separate subcontracts. N.Y. State Fin. Law \$ 135 ; N.C. GEN. Star. \$143-128 (1964); Ohio Rev. Code ANN. $\S 153.51$ (Page 1953) ; PA. STAT. ANN. tit. 53, \&1003 (1957). Massachusetts uses a complex preselection system for receiving separate subbids. The subbids are then forwarded to general contractors for use in preparing their prime bids, the awarding authority retaining the right to final approval of the subcontractor selected. MAss. GEN. LAws ch. 149, $\$ \$ 44$ A-44I (1955), as amended, MASS. GEn. Laws ch. 149, $\$ \S 44 A-44 I$ (Supp. 1963).

17 Secret competitive bidding is widely used in negotiating prime contracts on public building projects. CoHen, Public Construction Contracts and tHe Law $\$ 1.1$ (1961). This requirement was originally based in part on the assumption that public officials lack the requisite technical knowledge and personal involvement which would enable them directly to negotiate advantageous contracts on the open market. See Fones Hardware Co. v. Erb, 54 Ark. 645, 650, 17 S.W. 7, 8 (1891); Hannan v. Board of Educ., 25 Okla. 372, 377, 107 Pac. 646, 648 (1909). However, since general contractors do possess both the technical knowledge and the personal involvement assumed to be lacking in public officials, there would appear to be no need to limit the manner in which they negotiate their subcontracts.

18 These tactics, variously referred to as bid shopping or bid peddling, involve soliciting competitive subbids and then revealing the lowest subbid as a starting point for further open market bargaining. See Ring Constr. Corp., 8 T.C. 1070, 1075 (1947); Williams v. Favret, 161 F.2d 822, 824-25 (5th Cir. 1947) (dissenting opinion); Schueller, supra note 16 , at 498 n.6. It has been urged that such activity does not result in lowest prices either because the initial bids are made high knowing they are bargaining prices and hence the agreed price will not be the lowest possible but simply lower than any other, or because the competitive market at the time does not involve all the bidders, the lowest price is not obtained. See, e.g., Hearings on S. 1644 Before a. Subcommittee of the Senate Committee on the Jubdiciary, 84th Cong., 1st Sess. 90 (1955) [hereinafter cited as 1955 Hearings]. However, it would appear that if general contractors could get cheaper prices by using competitive bidding exclusively, they would do so since it would enable them to increase their profit margin. It has also been claimed that even if lower prices do result, use of such tactics often results in lower quality work on the part of subcontractors, a disadvantage to the public. See, e.g., CAI. Gov'T CODE $\$ 4101 ; 1955$ Hearings at 174. However, there is generally either an architect or engineer on the project who inspects the work in progress, thereby reducing any tendency to do shoddy work or use inferior materials. See Matera, Public Contracts-Authority of the Engineer, 47 MASs. L.Q. 379 (1962). For a further development of the arguments, see Schueller, supra note 16 , at $499-501$. 
procedure to secret competitive bidding. ${ }^{19}$ Hence subcontractors have, in many instances, established bid depository systems designed to facilitate and encourage such a procedure. $^{20}$ The defendant in Christiansen, for example, provided a facility which would collect sealed subbids from its members, hold them until four hours prior to the time set for submission of prime bids, and then deliver them to general contractors.21 Following award of the general contract, all subbids were tabulated and distributed to members who had participated in the bidding. ${ }^{22}$

19 A competent mechanical subcontractor incurs considerable expense in estimating a bid. See, e.g., Milone \& Tucci, Inc. v. Bona Fide Builders, Inc., 49 Wash. 2d 363, 364, 301 P.2d 759, 760 (1956) ; Hearings on S. 1644, H.R. 7637, H.R. 7638, H.R. 7668, H.R. 7676, H.R. 7686, H.R. 7693 Before a Subcommittee of the Honese Committee on the Judiciary, 84th Cong., 2d Sess. 131 (1956) (estimating cost of over $\$ 20,000$ on one project) [hereinafter cited as 1956 Hearings]. Thus, the subcontractor is understandably reluctant to have his bid revealed and used in negotiation with another subcontractor who need not necessarily have made an independent estimate but may simply be relying upon the work product of those who did as a means of making his own proposal. For other arguments, see, e.g., Engineering News-Record, May 23, 1963, p. 173 ("Bid Shopping Scorched by Subs"); Engineering News-Record, Jan. 29, 1959, p. 77 ("Can Bid Shopping Be Curbed"?).

$20 \mathrm{~A}$ considerable number of bid depositories exist in the United States, either in the form of legal entities organized ad hoc, or as adjuncts to other functions of various trade associations. Letter From William $\mathrm{H}$. Orrick, Jr., Assistant Attorney General, Antitrust Division, Department of Justice, to the University of Pennsylvania Law Revieze, Oct. 1, 1964, on file in Biddle Law Library, University of Pennsylvania; Engineering News-Record, Feb. 14, 1963, p. 29. Basic to depository operation is a central facility for the collection of subbids. Beyond this, two principal types of systems are employed. In the first type, upon request, both original subbids which are forwarded to general contractors and copies of the originals which are retained by the depository are collected for tabulation and distribution to all bidders at some later time. See United States v. Bakersfield Associated Plumbing Contractors, Inc., Trade Reg. ReP. (1958 Trade Cas.) If 69087 (S.D. Cal. May 26, 1958), modified, TRADE REg. ReP. (1959 Trade Cas.) I 69266 (S.D. Cal. Dec. 22, 1958). By setting a deadline beyond which subbids will not be accepted and then holding the subbids until a short time prior to prime bid opening time, the depository presumably can limit pre-award negotiation. This, of course, requires that depository members refrain from dealing directly with general contractors. Post-award "chiseling" is presumably discouraged by making a public record of the subbids and any necessary negotiation is carried on with full knowledge of what the original bids were.

The second type of system relies solely upon collecting copies of subbids for subsequent tabulation and publication. This system does not obligate the subcontractor to maintain prices he reports but gives him a basis for comparing his bids with others and resisting pressure. Thus, a self-imposed stability may be effected. This second type of system has been tentatively approved by the Department of Justice through its "railroad release" procedure. See Schueller, supra note 16, at 515-16. For a more detailed description of the procedures of a depository which reportedly received a "railroad release," see Engineering News-Record, Dec. 25, 1958, p. 124.

21 A principal complaint of general contractors is that they frequently receive subbids only minutes before they are required to submit their prime bids and hence are given no opportunity to check the bids for accuracy or the bidders for reliability. See, e.g., 1956 Hearings at 156, 165. Subcontractors attribute the lateness of the submission of subbids to the fear that their bids will be "shopped." See 1955 Hearings at 90 . The four hour period provided by the present depository appears to represent a reasonable compromise giving the general contractor sufficient time to evaluate his subbids while giving the stbcontractor some assurance that his bid will not be "shopped."

22 Defendant's practice of releasing the bid tabulations only to those members who participated in the bidding falls short of full disclosure which seems more desirable. However, a countervailing pressure is that subcontractors do not submit the same subbids to all general contractors and full disclosure might prove embarrassing. See Engineering News-Record, Sept. 27, 1962, p. 61. Interviews with members of 
These procedures reflect the generally accepted system often used for secret prime bidding and do not seem unreasonably restrictive in themselves. General contractors could unilaterally require a similar process, and the depository can thus be viewed simply as a means of providing this service for them. Difficulties arise, however, when subcontractors seek to do more than just make such a facility available. Although it may be only natural to do so, any attempts (1) to induce general contractors to use the facility, or (2) to encourage general contractors to use the subbids of depository members in preference to those of nonmembers, or (3) to enforce compliance with depository rules may lead to unreasonable restraints upon trade and, in some instances, to boycott.

Subcontractors may attempt to induce use of the system by agreeing to withhold subbids from nonparticipating general contractors. Such an agreement, whether embodied in depository rules or arrived at by mutual understanding, is prima facie evidence of a purpose to boycott and is illegal despite the lack of any evidence that it actually resulted in restraint of trade. ${ }^{23}$ In Christiansen the court found that "the rules tend to compel general contractors to affiliate with the Depository because of economic pressure in obtaining representative bids" and "encourage mechanical subcontractors bidding through the Bid Depository to boycott general contractors who do not sign the Depository agreement." ${ }^{24}$ However, the rules did not forbid members to bid outside the system and there was no prima facie evidence of any purpose, express or implied, to withhold bids from general contractors who did not use the system. ${ }^{25}$ This suggests

the construction industry in Philadelphia during August, 1964 revealed that subcontractors often submit lower bids to general contractors with a good reputation for prompt payment and efficient work scheduling. Individual working relationships may also be a contributing factor. It might be preferable, therefore, to publish only the amount of individual bids, omitting the name of the bidder.

23 See Associated Press v. United States, 326 U.S. 1, 12 (1945). In United States v. Bakersfield Associated Plumbing Contractors, Inc., Trade REg. REP. (1958 Trade Cas.) I 69087 (S.D. Cal. May 26, 1958), modified, Trade REg. Rep. (1959 Trade Cas.) \69266 (S.D. Cal. Dec. 22, 1958), a depository operation almost identical to that of the defendant in Christiansen was generally approved. The court specifically found no evidence of coercion to use the depository. Id., $\pi 69087$, at 74305.

Schueller, supra note 16 , at $528-30$, lists twenty-eight cases in which bid depository operations have been challenged by the Antitrust Division of the Justice Department since 1939 and notes that "with the possible exception of two situations, all bid depository cases listed . . showed elements of coercion or boycott . . . " Id. at 507. See generally $i d$. at 506-12. Schueller also notes that: "[V]ery few of the bid depositories attacked by the Antitrust Division for coercion or boycott relied on the strength of their members alone. In most cases, participation by labor groups, suppliers, or customers was alleged." Id. at 510. Thus, for example, a depository association could enter into an agreement in which a union would agree not to furnish labor to general contractors who failed to use the depository. There is no suggestion that such arrangements were present in the Christiansen case.

24230 F. Supp. at 190.

25 Portions of depository rule $\mathrm{V}$, quite to the contrary, provided that:

It is also to be understood that any general contractor who has not made a request for bids from the Depository may solicit mechanical bids from any person or firm that he desires, and that he is not obligated to use the Depository at all if he does not wish to do so. The Depository service will be available upon request from any general contractor on one or more of his 
that the court may have regarded a depository operation per se as tending naturally to result in boycott, and thus its mere existence would be sufficient evidence to show a combination in restraint of trade. It may be that individual subcontractors identify a general contractor's failure to use the depository system with a predilection to utilize "unfair" methods of negotiating subcontracts and, to that extent, the depository could be a covert means of creating a blacklist. However, to conclude that a depository will naturally compel or encourage subcontractors to boycott general contractors who fail to use it does not appear reasonable, and, in the absence of direct evidence that a boycott actually resulted, depository operations should not be condemned on that ground. ${ }^{26}$

The plaintiff in Christiansen argued, however, that depository rule $\mathrm{V}^{27}$ resulted in a boycott of nonmember subcontractors because a general contractor who wished to receive depository bids was required to agree in effect that he would not use bids from subcontractors who were not members of the association. ${ }^{28}$ The rule, it may be urged, is more rea-

jobs, without the general contractor thereby being committed or required in any way to use the service on other jobs.

$230 \mathrm{~F}$. Supp. at $193 \mathrm{n} .21$. These provisions appear to be in harmony with recommendations for effective depository operation found in Schueller, supra note 16, at 526-27.

26 If, in fact, a number of individual contractors were withholding subbids, the mere existence of the depository association would probably be sufficient additional evidence to show a combination or conspiracy to boycott. See Withrow, Trade Associations, 4 ANTITRUST BULL. 173, 177 (1959). This would obviate the difficulties sometimes faced by courts in "conscious parallelism" cases where nothing more than the business effect is shown and direct evidence of conspiracy or agreement is lacking. See Theatre Enterprises, Inc. v. Paramount Film Distrib. Corp., 346 U.S. 537 (1954); Delaware Valley Marine Supply Co. v. American Tobacco Co., 297 F.2d 199 (3d Cir. 1961), cert. denied, 369 U.S. 839 (1962); Turner, The Definition of Agreement Under the Sherman Act: Conscious Parallelism and Refusals To Deal, 75 HARv. L. REv. 655 (1962).

In Christiansen one general contractor did testify that "in order to be sure of getting representative bids it was necessary to join [use?] the Depository." $230 \mathrm{~F}$. Supp. at 191 n.13. In addition, one subcontractor testified that his company would not do business with any general contractor who was not bound by the rules. PostTrial Brief for Plaintiff, p. 20. However, this hardly seems sufficient to show concerted refusal to deal, see Bigelow v. RKO Radio Pictures, Inc., 150 F.2d 877, 885 (7th Cir. 1945), rev'd, 327 U.S. 251 (1946) (evidence that product previously available to plaintiff was unobtainable after alleged conspiracy); Johnson v. J. H. Yost Iumber Co., 117 F.2d 53 (8th Cir. 1941) (evidence of threats to cut off source of supply followed by inability to secure supplies), and the court was apparently unable to find other evidence of concerted boycotting. See 230 F. Supp. at 191 n.14.

$\mathbf{2 7}$ See note 3 supra.

28 Post-Trial Brief for Plaintiff, p. 26. Other depository rules were also attacked as unduly restrictive. Rule III prohibited the splitting of subbids into component elements such as plumbing only or heating only. Small contractors capable of performing in only one area could thus be excluded from bidding or forced to subcontract the work they were unable to perform to still other subcontractors-a practice which would limit their ability to compete effectively. Furthermore, this rule could also lead to a tying arrangement, illegal per se, by forcing general contractors to accept all the services furnished by depository members or none. $C f$. International Salt Co. v. United States, 332 U.S. 392 (1947).

Depository rule VIII allowed only members who submitted bids initially to rebid on a project for a period of ninety days. The rule contributes nothing to the stated objectives of the depository and would result in an arbitrary bar to subcontractors who inadvertently missed the first round of bidding or were unable to participate for other reasons.

The court held both rules illegal. $230 \mathrm{~F}$. Supp. at 189. 
sonably read as requiring nothing more than an exclusive dealing arrangement as a condition precedent to use of the depository. In its specific terms, the language of the rule does not require a refusal to deal with nonmembers, but rather an agreement to make exclusive use of depository bids. To read this language as requiring an agreement to boycott would effectively turn most exclusive dealing arrangements into agreements to boycott. Furthermore, the rule seems fair and reasonably necessary to effective depository operation. Subcontractors could hardly be expected to limit their freedom to negotiate by committing themselves to depository procedures without requiring a similar commitment to the procedures on the part of general contractors who wish to use them. So long as the general contractor's initial decision to use the depository is not coerced, rule $\mathrm{V}$ seems to require nothing more than a simple quid pro quo for the association's furnishing the service. Thus it is necessary to examine the "practical effect" of the rule. ${ }^{29}$

The Christiansen court's finding that plaintiff was "substantially excluded from the opportunity of competing" 30 may have been somewhat premature since there was no showing that plaintiff had been denied depository membership or that membership requirements were, in fact, discriminatory or restrictive. ${ }^{31}$ In Associated Press $v$. United States, ${ }^{32}$ the Supreme Court considered a rule which forbade sale of Associated Press news to newspapers which were not members of the association and held it illegal only so long as there were discriminatory restrictions placed upon becoming a member. ${ }^{33}$ In the Christiansen case, it can be argued that if plaintiff was excluded, it was only because of his unilateral decision not to participate in the depository procedures.

It is questionable whether a depository should require membership at all since the benefit provided is essentially nothing more than the opportunity to do business in a particular manner. Membership requirements do not seem to be a sine qua non of effective operation of a depository and are clearly open to abuse since they can be employed at will to exclude

29 See notes 13-15 supra and accompanying text.

$30230 \mathrm{~F}$. Supp. at 194.

31 The rules stated:

Any person, firm, partnership or corporation in the plumbing, heating, ventilating and air-conditioning industry, operating as contractors from a recognized place of business, and who meets the licensing requirements of the State of Utah may become members of the depository.

Rules and Regulations of the Utah Mechanical Contractors Bid Depository-Qualification of Members of the Depository.

32326 U.S. 1 (1945).

33 Id. at 21-22. The Associated Press by-laws, in addition to the sales prohibition, clothed individual members with the power to impose restrictive conditions upon admission of business competitors while permitting relatively free admittance to noncompetitors. The Court did not proscribe restrictive membership requirements per se but held only that whatever requirements were established had to apply equally to all applicants. However, in United States y. Terminal R.R. Ass'n, 224 U.S. 383, 411 (1912), the Court directed that a decree be entered requiring a group of railroads to submit a plan whereby other railroads could gain admission to ownership of a jointly owned facility under "just and reasonable terms" and whereby nonowners could have free use of the facility. 
potential competitors from the market. ${ }^{34}$ Nevertheless, absent a showing that membership requirements were unduly restrictive, it is not clear how defendant's rule $V$, either in purpose or effect, actually foreclosed plaintiff from a substantial share of general contractors' business. ${ }^{35}$

However, even if no boycott of nonmembers resulted from the operation of rule $\mathrm{V}$, the spectre of boycott may arise from still a third sourcethe depository's attempt to enforce compliance with its rules and the exclusive agreement. In addition to denying further depository use to general contractors who violated their agreement, the defendant's regulations included provisions for suspending members for violation of depository rules. ${ }^{36}$ It is apparent that these enforcement provisions, by contemplating the exclusion of members from further opportunity to deal with those general contractors who continued to use only depository bids, would result in a boycott since the suspended subcontractor would no longer have access to the system. ${ }^{37}$

In addition, the defendant's practice of notifying members of the names of general contractors who violated the exclusive agreement can be viewed as creating a blacklist. In Eastern States Retail Lumber Dealers' Ass'n $v$. United States, ${ }^{38}$ the Supreme Court inferred a conspiracy to boycott from the practice of circulating to members of a retail lumber dealers' association a list of names of wholesalers who engaged in "unfair" trade practices. Although it can be argued that the defendants in Christiansen were simply trying to enforce an agreement, ${ }^{39}$ the identification of violators was clearly

34 For example, in the Christiansen case, the requirement that the contractor be operating out of a "recognized place of business," see note 31 supra, could be used to exclude the small, marginal contractor who maintains no offices but works out of his home. Similarly, it is not clear what effect the state licensing requirement would have on contractors outside the state who might wish to bid on a Utah project, especially since such contractors may not have occasion to use the services more than a few times.

35 If plaintiff was not foreclosed, he should have been denied recovery even though other aspects of the depository operation were found to be illegal, since his injury could only be compensable if a proximate result of the operation and enforcement of rule $V$. A further countervailing evidentiary factor is that, despite his alleged foreclosure from the market while rule $V$ was in effect, plaintiff received a higher percentage of the total contracts awarded than he did during eleven months of depository operations before adoption of the rule. $230 \mathrm{~F}$. Supp. at 194.

36 Rule VII provided that: "Any member, after a hearing, and who has been found by a majority of the committee to have failed to comply with the rules and regulations of the depository $\cdot{ }^{\circ}$ may be suspended from the depository, and further membership denied." $230^{\circ} \mathrm{F}$. Supp. at 189.

Courts have been unsympathetic to such policing provisions, viewing them as attempts to set up "extra-judicial tribunals" which impinge upon the power of the legislature. See Fashion Originators' Guild of America, Inc. v. FTC, 312 U.S. 457, 465 (1940); Union Circulation Co. v. FTC, 241 F.2d 652, 658 (2d Cir. 1957); Withrow, supra note 26 , at 182 .

37 In United States v. Nationwide Trailer Rental Sys., Inc., TRADE REg. REP. (1955 Trade Cas.) II 68101, at 70574 (D. Kan. July 2, 1955), aff'd mem., 355 U.S. 10 (1957), the court found that a trade association by-law providing for expulsion of a member if necessary "to keep this System out of legal entanglements or to preserve the good name and business of the System," constituted an agreement to boycott in violation of the Sherman Act.

38234 U.S. 600 (1914).

${ }^{39}$ Cf. United States v. General Motors Corp., 216 F. Supp. 362 (S.D. Cal. 1963). 
unnecessary to enforcement of depository rules since the association already had the power to deny further depository use for noncompliance. Thus the notification of members could serve no purpose other than to induce their refusal to deal with such general contractors outside the depository system. ${ }^{40}$

In view of the foregoing discussion, the question becomes what, if anything, can an association of subcontractors do to encourage the use and effective operation of a depository system. While an answer applicable to all situations is impossible, it would seem reasonable to assume that simple persuasion should be permissible.41 Yet the position of an individual depository may be such that even persuasion may tend to restrain unreasonably. The very nature of a bid depository association, its concerted and consensual character, its economic significance vis-à-vis the individual contractor, and its stated purpose of providing the best means for contractors to carry on a vital portion of their business, places it in a position of considerable economic power. It has been noted that:

[Restraint of trade] may exist although it is not manifested in any overt act, and even though there is no intent to restrain. Words of advice seemingly innocent and perhaps benevolent, may restrain, when uttered under circumstances that make advice equivalent to command. For the essence of restraint is power; and power may arise merely out of position. ${ }^{42}$

Any pressure, even though considerably short of boycott, may result in restraint of trade because of an individual contractor's natural and reasonable reluctance to fly in the face of such power. Even though the depository contemplates no boycott, a general contractor, faced with a "suggestion" that he would get more subbids if he used the depository, may be forced to consider carefully what will happen if he refuses and might reasonably decide that use of the depository is preferable to the possibility that he may find it difficult to get subbids otherwise..$^{43}$,

${ }^{40}$ Cf. Eastern States Retail Lumber Dealers' Ass'n v. United States, 234 U.S. 600,612 (1914).

41 In Paint Dealers Institute of New York City, FTC Dkt. 6367, Trade Reg. Rep. $\llbracket 26890$ (1957), a complaint that a trade association conspired to force manufacturers of paint to sell only to recognized independent dealers was dismissed for lack of evidence. The examiner said:

It appears that the respondents in this proceeding limited their activities to explaining the services of the independent dealer and the advantage of selecting him as a prime outlet for the products of manufacturers . . . This does not constitute a per se violation of law, and illegality cannot be inferred from this conduct alone.

42 American Column \& Lumber Co. v. United States, 257 U.S. 377, 414 (1921) (Brandeis, J., dissenting). The court in United States v. Bakersfield Associated Plumbing Contractors, Inc., TRADE Reg. REP. (1959 Trade Cas.) \ 69266, at 75037-38 (S.D. Cal. Dec. 22, 1958), perhaps in recognition of the danger inherent in such power, retained jurisdiction and provided for continuing inspection of the depository operation by the Department of Justice.

43 It does not seem unreasonable to assume that it was this consideration that prompted the testimony of one general contractor in the Christiansen case that he 
Whether or not this power can be completely negated is open to question. However, certain steps may be suggested. First, the administration of the depository should be entrusted to a disinterested third party such as a bank or legal office. ${ }^{44}$ This would serve to insulate users of the service from arguably coercive contacts with members of the association sponsoring the depository. In any event, association members must be impressed with their duty to refrain from any acts or statements which could be interpreted as an attempt to exert pressure to use the system. Second, use of the service should be open to all. Even though association membership requirements may be so liberal as to amount to a mere formality, the formality is clearly not necessary, and completely free access to the depository seems more compatible with the spirit of the enterprise. Third, any tendency to abuse the system is probably best prevented by continually exposing the process to public observation. ${ }^{45}$ Thus provision should be made for full disclosure of all depository operations, including the publication of bid data following submission of the bids. Such bid data need not necessarily include the names of bidders but should be open to all interested parties. ${ }^{46}$ Beyond these controls, enforcement provisions of any kind cannot be tolerated. The depository must rely solely upon the benefits supposed to be inherent in the system to induce use of its procedures and to ensure compliance.

felt it necessary to request bids from the depository. 230 F. Supp. at 191 n.13. Thus it is possible under the specific circumstances of this case, that it was reasonable for general contractors to feel restricted by the mere existence of the depository and that the restraint, although not a boycott, was unreasonable under a rule of reason approach. Such a finding, however, would not necessarily entitle plaintiff to recover in a private suit for, while it has been held that public injury need not be shown where a per se violation exists, Radiant Burners, Inc. v. Peoples Gas Iight \& Coke Co., 364 U..S. 656 (1961) ; Klor's, Inc. v. Broadway-Hale Stores, 359 U.S. 207 (1959), there has been no similar holding in cases decided under the rule of reason. Moreover, one commentator has expressed the opinion that a public injury requirement survives outside the per se area. Handler, supra note 9, at 865-66.

44 This device is used by the depository reportedly given a "railroad release" by the Department of Justice. Engineering News-Record, Dec. 25, 1958, p. 124. One source has suggested that privately owned, profit motivated depositories might prove more effective than those operated by industry groups. Engineering News-Record, Feb. 14, 1963, p. 29.

45 A collateral benefit of such disclosure would be to bring the depository to the attention of builders, architects and awarding authorities who might then request general contractors to make use of the service. Architects, in particular, have expressed concern over the practices of bid peddling and bid shopping, see AMrerICAN INSTITUTE OF ARCHITECTS, HaNDBOoK OF ARCHITECTURAL PRACTICE § III-7.02 (8th ed. 1958), and might be expected to insist upon use of the depository.

46 See note 22 supra. In United States v. Bakersfield Associated Plumbing Contractors, Inc., TrADE REg. REP. (1959 Trade Cas.) T 69266, at 75037 (S.D. Cal. Dec. 22 , 1958), the court entered a decree ordering the.depository to "announce and publish" all bids at a specified time after giving notice of such bid openings to all interested parties. 